\title{
A leadership model validation: Dimensions influential to innovation
}

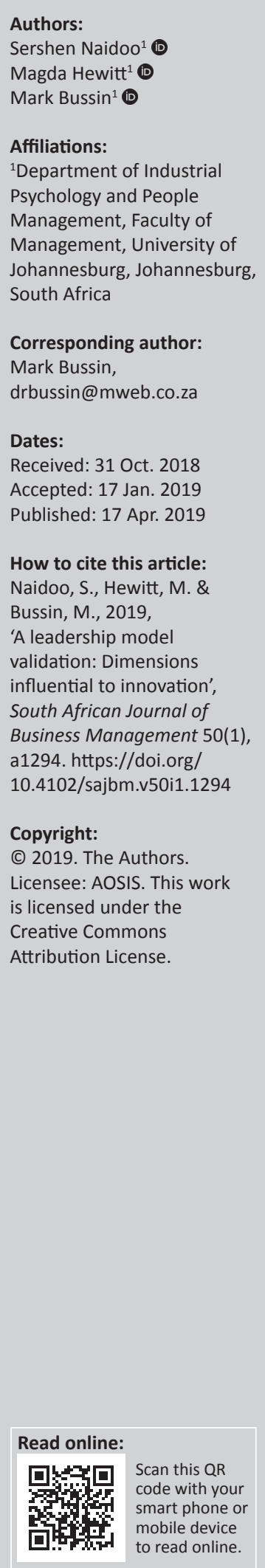

Background: Current pressures for globalisation force organisations to explore, create and implement new ideas in order to remain competitive. This necessitates the need to utilise innovation to diversify products and services, introduce new technology, establish new managerial and administrative practices, and initiate transformation in other areas of the organisation.

Objectives: This article explored the relationship between the latent variables, namely, rewards, resources, leadership vision and innovation, as postulated by De Jong and Den Hartog's leadership model for stimulating innovation.

Method: The research approach chosen to investigate the research questions was an ex post facto, cross-sectional field survey. Secondary data from a reputable financial institution with extensive business in three African countries (Botswana, Lesotho and Namibia) were used as the data were collected by the institution and made available to the researcher for further analysis. A complete sample size of $N=584$ was obtained across the three countries. Confirmatory factor analysis was initially used to provide a confirmatory test of the measurement theory followed by structural equation modelling which allowed to test for regression amongst the latent variables (rewards, resources, leadership vision and innovation).

Results: Structural equation modelling revealed that only leadership vision and resources were found to be statistically significant; rewards showed a negative relationship $(r=-0.02)$ with innovation. Resources made the greater contribution $(r=0.75)$ to innovation, compared to leadership vision $(r=0.28)$.

Conclusion: The study empirically validate and support the assertion of De Jong and Den Hartog (2007) that the latent variables resources and leadership vision positively correlate with innovation in the context of the financial services industry.

Keywords: Innovation; reward; resources; leadership vision; sub-Sharan.

\section{Introduction}

The ever-evolving globalised business environment of the past two decades has seen significant changes in the manner in which organisations operate (Liao, 2006). Continuous re-evaluation of workplace optimisation and strategies is imperative for long-term survival (Slettan \& Mehmetoglu, 2011) in a cut-throat environment shaped by technological advancements, legislation, increased competition, customer expectations and an unpredictable economic climate. Flexibility and responsiveness to transformation enable organisations to face challenges, stay ahead of competitors, generate profits and create a working environment that enhances employee productivity and increases job satisfaction (Aryee, Walumbwa, Zhou, \& Hartnell, 2012). The rapid changes and challenges encountered by organisations necessitate the exploration of new ideas to remain competitive. This necessitates innovation to diversify products and services, introduce new technology, establish new managerial and administrative practices, and initiate transformation in the organisation (Scott \& Bruce, 1994; Zhao, 2005).

Employees play a vital role in building an innovative workplace in terms of processes, procedures and functions. Akhtar (2010) emphasised that 21st century employees should employ creative thinking and innovative problem-solving practices to position themselves and advance their careers. In addition, Collins (2012) stated that leaders play a critical role in motivating employees and cultivating innovative behaviour. As leaders are regarded as the driving force of innovation in organisations, it is imperative that research be conducted to assist captains of industry and commerce to gain insight into the relationship between leadership and innovation. 
An understanding of influential leadership behaviours and characteristics is crucial in fostering successful innovative behaviour by employees in an organisation (Vroom \& Jago, 2007). Understanding the relationship between the latent variables investigated in this study - rewards, resources, leadership vision and innovation - will allow leadership to understand what might contribute to the generation and implementation of innovative ideas, thereby increasing the organisation's innovation. Leaders could use the findings of this study as managerial tools to stimulate innovative output, thereby cultivating an innovative culture throughout the organisation. This, in turn, will lead to a competitive, highperformance organisation.

The key focus of the study was to validate the relationships between the latent variables, rewards, resources, leadership vision and innovation, as extracted from De Jong and Den Hartog's (2007) conceptual framework for stimulating innovation.

\section{Literature review Innovation}

Mankind's progression over time has been marked by revolutionary transformation while challenging the unknown and continuously improving the lives of people (Zauškováa, Bobovnickýa, \& Madleňáka, 2013). Ever-intensifying competition, the effects of the globalisation of organisations, the constant evolution of markets and technologies, and changes in regulation and customer demands have forced companies to focus on innovative strategies to maintain a competitive advantage (Gumusluoğlu \& Ilsev, 2009; Leiva, Culbertson, \& Pritchard, 2011). Furthermore, the fast-paced business environment calls for continuous change and variation, as well as innovative leadership, to endure these complexities and turbulence (Cooper, 1998; Ju, 2012). Businesses worldwide are embroiled in an innovation war with the principal purpose of differentiation.

The innovation process is synonymous with the creation of new ideas and knowledge that will translate into original products and services to create value-added outcomes with increased efficiencies (Lin \& Chang Jung, 2006; Zauškováa et al., 2013). The concept of creativity is recognised as the development of new and valuable ideas with a practical application and implementation (Gumusluoğlu \& Ilsev, 2009). Cook (1998) described creativity as essential for achieving a competitive advantage and when a company wants to expand its business operations through unique products and services.

Organisations can profit from innovation by gaining a competitive edge over less innovative competitors through the generation of novel products and services and improved business processes (Jafri \& Bhutan, 2010). Afuah (1998) described the outcome as reduced costs, enhanced efficiencies, increased quality, and products or services not previously offered to the market. Employees are at the heart of all organisations, and successful innovation requires that their creative ideas are unleashed, supported and promoted (Scott \& Bruce, 1994).

Several researchers favour a positive correlation between innovation by individuals and all aspects of business complementary to increased organisational success and improved economic growth and performance (Smith, 2002; Unsworth \& Parker, 2003; Wiklund, Patzelt, \& Shepherd, 2009). This innovation may lead to the development of new products, services and technology, as well as improvements to existing products and the creation of new value chains (Roy, Sivakumar, \& Wilkinson, 2004). Subramaniam and Moslehi (2013) stressed that it is a prerequisite that organisations innovate in order to realise supreme levels of performance.

The innovation process is recognised as a discipline that can be learned and practised (Lin \& Chang Jung, 2006). Researchers Elenkov and Manev (2005) proposed that innovation can become a core competency within an organisation, if this is envisioned and supported by leadership. Innovation is rarely performed by higher leadership directly; it generally originates from lower and mid-level managers and employees. Practitioners Subramaniam and Moslehi (2013) emphasised that, when leadership fails to consider innovation as an important approach and to develop innovative capacity within the workforce, organisational performance stagnates and declines, and the organisation ultimately becomes vulnerable to competitors who value and appreciate innovative practices.

It is apparent that organisations are broadening their initiatives to drive a stronger innovative culture. Organisational practices such as recruitment, selection and retention are receiving greater cognisance in terms of potential and current employees' propensity to innovate (Subramaniam \& Moslehi, 2013). However, while innovation is generally proposed by employees, leadership has to fulfil the critical function of support, motivation and guidance during the innovation process (Collins, 2012).

Woods (2013) is of the view that a key responsibility of a leader is to develop employees as 'leaders' in their positions and to enable them to improve efficiencies and effectiveness. Leadership efforts should therefore be focused on creating conditions conducive to innovative activities by employees, in alignment with business operations. Leaders have to enhance their knowledge of the innovative process, so that they are able to provide and manage resources effectively while cultivating innovative behaviour to achieve organisational aspirations (Gumusluoğlu \& Ilsev, 2009; Shin \& Zhou, 2003).

The qualitative study conducted by De Jong and Den Hartog (2007) on individual innovation proposed an inventory of leadership dimensions that may influence employees' propensity to innovate within a knowledge-intensive service 
industry, paying specific attention to both the generation of ideas and employees' behaviour. They identified 13 different leadership dimensions through an extensive literature review and reported on interviews with both innovative and noninnovative groups of individuals. Each of these dimensions has a significant influence on the way ideas are formed and the application of these ideas.

For the purpose of this study, the interaction between the four latent variables proposed in the aforementioned study rewards, resources, leadership vision and innovation (as highlighted in Figure 1) - was selected for further study. The data obtained pointed to the selection of the four variables as a point of departure, with the view to testing the model in its totality at a later stage. Figure 1 is a depiction of De Jong and Den Hartog's (2007) conceptual framework for stimulating innovation.

\section{Rewards and innovation}

The exploration of motivational factors that influence employees has become an area of interest in research. George and Zhou (2001a) perceive human behaviour to be changeable through the provision of rewards. Rewards psychologically change human thought processes, emotions and behaviour. Rewards that satisfy the desire for self-fulfilment have a significant influence on an individual's commitment to activities (Deci \& Ryan, 1987). Yukl (2002) constructed a comprehensive classification of types of leadership behaviour and found that rewarding employees is an effective management tool in contributing towards employee performance. Furthermore, innovation literature asserts that

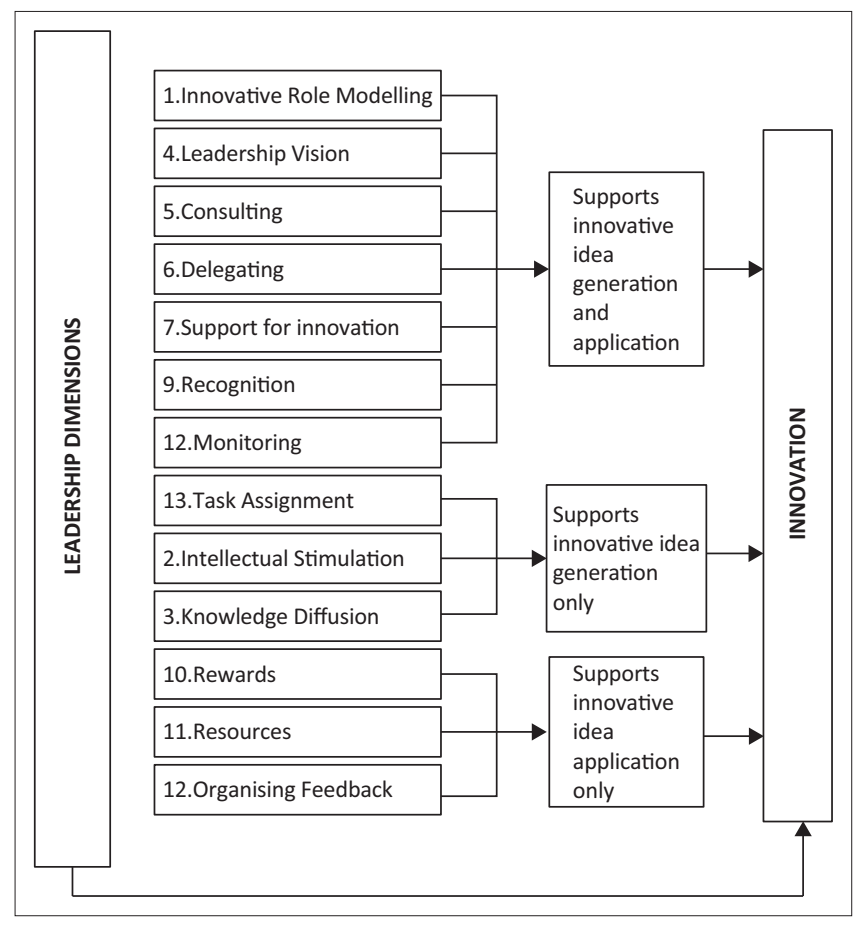

Source: De Jong, J. P. J., \& Den Hartog, D. N. (2007). How leaders influence employees' innovative behaviour. European Journal of Innovation Management, 10(1), 41-64. https:// doi.org/10.1108/14601060710720546

FIGURE 1: De Jong and Den Hartog's (2007) conceptual framework for stimulating innovation. self-motivation and enthusiasm are fundamental to employee creativity and innovative behaviour (Cavagnoli, 2011). Cave (2002) emphasised the significance of workplace stimulation and incentives and noted that sustaining employees' enthusiasm and motivation requires that organisations encourage employees and support their continued interest.

A core debate in the field of reward management is the balance between extrinsic and intrinsic rewards. Extrinsic rewards are, for example, financial incentives. However, extrinsic rewards are not the sole driver of employee behaviour. Equally important are intrinsic rewards - internal motivational factors that influence employees on a more personal level. Examples of such motivators are work culture, organisational values, work-life balance, autonomy, career advancement and promotional opportunities, acquisition of skills, and learning and development (Campbell-Allen, Houston, \& Mann, 2008).

Bragg (2000) developed a taxonomy of principles pertaining to successful reward schemes. He noted that, in order to drive and sustain organisational success, reward systems must support the organisation's strategy and goals, while also rewarding the employee behaviours that need to be continuously repeated. Poster and Scannella (2001) support this view, stating the need for equilibrium and alignment between the employer's and the employees' goals.

Rewards influence thought processes and, therefore, emotions and actions (Deci \& Ryan, 1987). Practitioners exploring the harnessing of employee creativity and employee innovation have found a relationship between extrinsic rewards and creative thinking - when rewards are directed at innovating thinking, reward beneficiaries display more creativity (Walton, 2003; Yukl, 2002). Research by Kuratko (2009) confirmed the positive correlation between financial rewards and innovative behaviour displayed by employees, leading to innovation. Rewards after the fact or expected rewards in the form of share options, profit-sharing and team incentives have been empirically proven to enhance employees' innovative behaviour and output (Antikainen \& Väätäjä, 2010; Mudhi \& Boutellier, 2011).

Antikainen, Makipaa and Ahonen (2010) argue that financial rewards alone are not sufficient motivators to promote innovation. Both intangible, intrinsic rewards and extrinsic rewards are required to initiate creativity and enhance innovative outcomes (Deci, Koestner, \& Ryan, 1999; Hennessey \& Amabile, 1998). Examples of intrinsic rewards are training and skill-enhancing opportunities (Hennessey \& Amabile, 1998); providing guidance and performance feedback (Zhou, Zhang, \& Montoro-Sanchez, 1998); job flexibility, autonomy and empowerment (Oldham \& Cummings, 1996; Tierney \& Farmer, 2004); career development and job progression (Gupta \& Singhal, 1993); positive interpersonal relationships (Ruppel \& Harrington, 2000); and organisational recognition (Antikainen \& Väätäjä, 2010). Studies on innovative behaviour have found that the optimal rewards scheme for driving innovation is a 
mix of several types of extrinsic and intrinsic rewards (Cavagnoli, 2011).

Therefore, the following hypothesis was formulated:

H1: Rewards (independent variable) has a positive relationship with innovation (dependant variable)

\section{Resources and innovation}

Innovative efforts are generally demanding activities that require time and perseverance (Collins, 2012; Mathisen, 2011; Tierney \& Farmer, 2004). It is therefore crucial that the leader is supportive of the innovative process and makes available resources such as money and time, while allowing employees autonomy, to ensure they remain stimulated and optimistic and continuously explore innovative practices (Mathisen, 2011).

There is extensive support for the notion that financial constraints have a limiting effect on creativity and innovation (Amabile, Conti, Coon, Lazenby, \& Herron, 1996; Damanpour, 1991; Weiss, Hoegl, \& Gibbert, 2011). Research by Jarousse (2012) highlighted that, in addition to organisational efforts to craft a positive attitude towards innovation, leadership needs to allocate sufficient resources for innovative behaviour to flourish and become sustained. Consistent with this view, Negrusa, Gica and Cosma (2008) posited that the availability and provision of resources required to innovate is one of the key needs in creating an innovative organisation. While organisational climate and support are essential, these alone will not facilitate full commitment to innovation. The provision of resources in the form of time and money reflects the organisation's intent to drive and encourage employee creativity and innovation (Conroy, 1987).

Human nature leads people to take on the direction of least resistance. Encountering challenges such as constrained financial resources indicates a restricted path and creates uncertainty, which inhibits creative thinking and innovation (Ward, 1994; Weiss et al., 2011). In investigating the outcome of innovative projects in Korean high-tech industries, Song and Noh (2006) established that the provision of resources significantly enhanced innovation outcomes. This finding was supported in a later evaluation of 1014 Korean manufacturing firms by Jang and Chang (2008).

Amabile et al. (1996) found that granting employees sufficient freedom is a key determinant of innovation. Their research concluded that individuals who are allowed sufficient time and autonomy in their work activities demonstrate higher levels of creativity and innovation. George and Jones (2008) also view the increase of personal autonomy as a mechanism to encourage and promote innovation and, ultimately, improve organisational efficiency. In addition, Woods (2013) is of the opinion that an increase in supervision minimises the flexibility and autonomy of subordinates and suppresses inspiration, creativity and innovation. Google Corporation's 80-20 autonomous management practice is testament to the fact that allowing sufficient autonomy does lead to higher levels of employee innovation. The policy allows their engineers to use $80 \%$ of their time on assigned tasks and the remaining $20 \%$ on self-directed projects. This has resulted in many successful innovative product ideas emerging, which have been integral to Google's success (Amar, Hentrich, \& Hlupic, 2009).

Finding a balance between employee supervision and creativity creates a dilemma for management. If it is accepted that creativity enhances performance, then a rigid organisational structure is inconsistent with enhancing performance (Subramaniam \& Moslehi, 2013). Collins (2012) suggested that there should be an equilibrium between supervision and creativity, which may even require a complete organisational transformation of structure and culture. When an organisation enforces control across all levels, flexibility and innovative activities are stifled, and any recruitment of new employees favours a 'safe' profile that will blend in with the organisation (Allcorn, 2012).

Zhao (2005) posited that a culture of empowerment is a fundamental stimulus for innovation, not the one in which employees fear the consequences of failed risk-taking. In addition, Glynn (1996) argued that, in an ideal organisation, to enhance innovative outcomes, control is decentralised and employees performing the actual tasks are given latitude in decision-making. Furthermore, practitioners Axtell et al. (2000) pointed out that innovation can be supported by relaxing control and structure, to become more flexible and less formalised, and by giving the workforce the confidence to take risks, experiment and challenge the status quo, without being reprimanded.

Woods (2013) supports giving employees structured autonomy within prescribed boundaries and further explains that it is not the leader's task to inform employees how to complete an assignment, as this will confine employees to a focus on detailed instructions, which will discourage original problem-solving and innovative thinking. A leader should focus on creating the framework and conditions to ensure that the task is completed efficiently (Amar et al., 2009).

Therefore the following hypothesis was formulated:

H2: Resources (independent variable) has a relationship with innovation (dependant variable).

\section{Leadership vision and innovation}

According to Nanus (1996), vision refers to the expressed intentions, desires and aspirations of an organisation or individual that propel future actions and these entail the allocation of resources towards realisation of the vision. This vision is the ideal future or envisaged state of the organisation (O'Conell, Hickerson, \& Pillutla, 2011; Schermerhorn, 2005). James and Lahti (2011) stated that an organisation's vision is a statement of objectives, which should be one that employees can honourably pursue. It represents the direction and guidelines for achieving what the organisation should be in the future, as well as the strategy the company needs to 
follow to this end (Camelo-Ordaz, Fernandez-Alles, \& ValleCabrera, 2008; Raynor, 1998; Revilla \& Rodriguez, 2011; Schwarz \& Nandhakumar, 2002).

O'Conell et al. (2011) reviewed a wide spectrum of literature and concluded that, in comparison to strategy, vision requires a longer time frame (where the company wants to be in 10-20 years). They further highlighted that, when company vision is clear, it will lead to innovative strategic initiatives to realise the company vision. Mukundan (2006) researched the effect of innovation on competitive advantage and concluded that a company should have a concise vision, in line with the company's character. Therefore, supplementing the vision with organisational values and principles is recognised as assisting leadership in influencing followers to enthusiastically pursue anticipated organisational proposals (Senge, 1990; Slack, Orife, \& Anderson, 2010). Moreover, futuristic leaders confront the unknown by instilling in their followers a sense of confidence and reassurance that they will realise their aspirations through visionary leadership (Starratt, 1995).

Although studies of vision and innovation appear to have gained interest in isolation over the years, there is emerging support for linking organisational vision to creativity and innovation (Balkin \& Gomez-Mejia, 1990). Research by O'Conell et al. (2011) and Slack et al. (2010), for instance, concluded that vision has a significant relationship with individual employee creativity and stimulation, as well as team innovation, which inevitably translate into improved organisational performance. Similarly, Chandi and Tellis (1998) studied a sample of over 300 German companies and found that leadership's vision has a strong positive impact on innovation. In empirical studies on innovation predictors, Hülsheger, Anderson and Salgado (2009) found statistical associations of vision and creativity with individual and team innovation. Slettan and Mehmetoglo (2011) investigated the relationship between the two variables in the hospitality industry and also found favourable correlations.

Liao (2006) found a positive relationship between a shared vision and employee innovation and attributed a collective vision to a sense of organisational purpose and direction. A shared vision is likely to promote employee collaboration, sparking new ideas while employees aspire to achieve the goals. This indicates that a definitive visionary direction is a core company competency and an internal strength (Calcantone, Cavusgil, \& Zhao, 2002). However, innovation will be unattainable if multiple agendas exist within the organisation. Clear articulation of a vision enhances cohesive efforts and visualisation of priorities and direction (Campbell \& Collins, 2001).

Slettan and Mehmetoglo (2011) stated that exhibiting the organisational vision is a fundamental technique used by effective leaders to encourage and motivate supporters by portraying a desired image of the future. Moreover, they posited that an organisational vision is a key contributor to employee creativeness and innovation. A persuasive vision of achieving excellence is believed to give employees a sense of importance, which encourages them to acknowledge and execute the organisation's aspirations (Finkelstein \& Hambrick, 1990). Leadership ambitions that are motivating, vibrant and innovative will cultivate innovative outcomes (Itami \& Numagami, 1992). Camelo-Ordaz et al. (2008) emphasised that innovation becomes stagnant when management portrays uninspiring and imitative mental characteristics (management pretends that everything is under control and there is no sense of urgency). In summary, an innovative vision will encourage employees to search beyond conventional products and solutions (Kim \& Kogut, 1996; Nobeoka \& Cusumano, 1997).

Therefore, the following hypothesis was formulated:

H3: Leadership vision (independent variable) has a relationship with innovation (dependant variable).

The hypothesised confirmatory factor analysis (CFA) firstorder leadership measurement model stemming from the preceding literature review is presented by the authors in Figure 2.

The last hypothesis (H4) was formulated as follows:

H4: There is a significant fit between, amongst and with the latent variables, resources, rewards, leadership vision and innovation.

\section{Research methodology}

The purpose of this study was to determine the relationships of the latent variables: Resources, Rewards, Leadership vision and Innovation. A quantitative approach was used for the following reasons:

- De Jong and Den Hartog (2007) developed qualitatively a theoretical model that requires empirical validation.

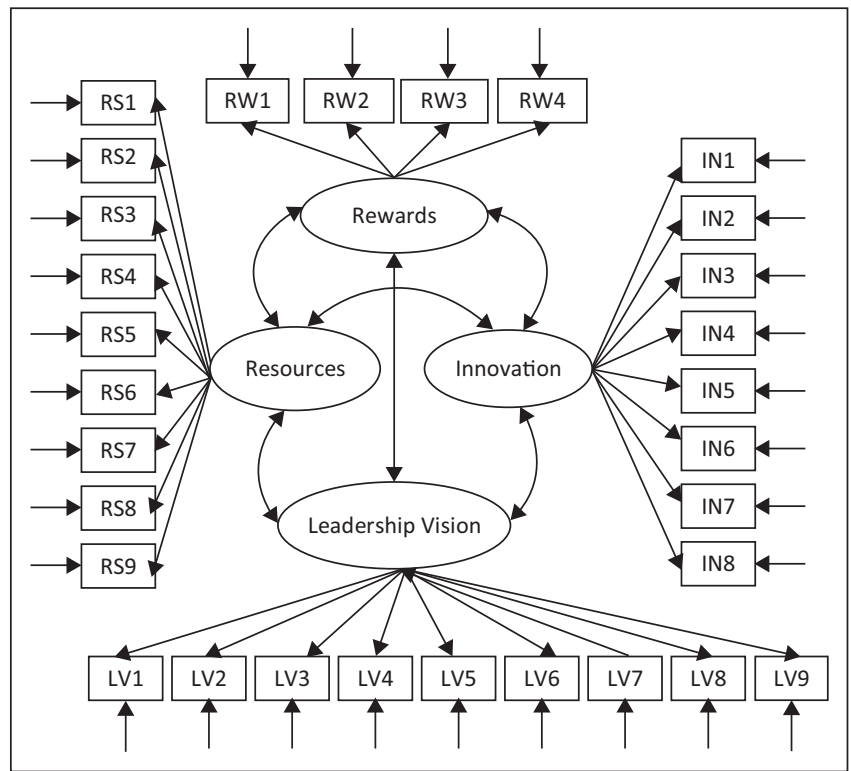

FIGURE 2: Hypothesised confirmatory factor analysis first-order leadership measurement model for testing. 
- Standardisation of research questions permits a uniform research approach that will allow the researchers to administer the same set of questions to a larger set of the general population in future (Parker, 2007).

- A quantitative design allows for the generalisation of the study results to the population when using a representative sample (Morton, 2011).

The research approach chosen to investigate the research questions was an ex post facto, cross-sectional field survey. Secondary data from a reputable financial institution with extensive interests in three African countries (Botswana, Lesotho and Namibia) were made available to the researcher for further analysis, in order to make generalisations about the greater population (Zikmund, Babib, Carr, \& Griffen, 2011).

\section{The research method}

The research method is discussed under the following headings: Population, sampling and respondents; measuring instrument; and, lastly, statistical analysis.

\section{Population, sampling and respondents}

A sample of $N=582$ was drawn from a financial institution. The sample represented all departments in all regions in Botswana, Lesotho and Namibia in which the organisation under study has operations. The representation per country was Botswana $(n=200)$, Lesotho $(n=182)$ and Namibia $(n=200)$.

\section{Measuring instrument - self-administered survey questionnaire}

As part of an annual human resources (HR) project, a selfadministered survey questionnaire is used by the financial institution to measure employee engagement (refer to Annexure B). Questions are answered on a Likert scale with five response options, ranging from strongly disagree to strongly agree.

The self-administered survey questionnaire comprises two sections, namely, Section A (Biographical Data) and Section B (Survey Questions). For the purpose of this study, it was decided not to report on the biographical data of the respondents, as these data were not the focus of the study. Section B of the self-administered questionnaire comprised 13 latent variables, of which four were selected for this study, namely, rewards (four items), resources (nine items), leadership vision (nine items) and innovation (nine items), because of the availability of raw data on these dimensions.

\section{Statistical analysis}

The data were analysed using Mplus (Version 7.3). Firstly, descriptive statistics were calculated to describe the data for the whole sample, as well as for the respective countries, that is, Botswana, Lesotho and Namibia. Structural equation modelling (SEM) was then applied to investigate the theoretical measurement and structural models, and to examine the predictive value of resources, rewards and leadership vision in relation to innovation in the proposed model.

Structural equation modelling was chosen because it is not limited to a single statistical technique. It is a multivariate statistical modelling technique that includes a family of statistical methods, such as covariance structural analysis, latent variable analysis, exploratory and CFA, path analysis and regression (Hair, Anderson, Tatham, \& Black, 1995; Kline, 2011). Hair et al. (1995) highlighted two aspects of SEM, namely that it has the ability to account for unobserved concepts (the factors) in interrelated dependence relationships, and it can account for measurement errors in the estimation process. Structural equation modelling is also an estimation of multiple and interrelated dependence concepts. Structural equation modelling further refers to the combination of the measurement model, with latent variables defined by observed variables and a structural regression model that links latent variables together (Figure 2) and numerically indicates the strength of their relationships. For the purpose of this research, SEM was applied to examine the relations between the indicators (observed variables) of rewards, resources, leadership vision and innovation and their associated latent variables (factors), as derived from the CFA.

\section{Results}

The outcome of the hypothesised CFA leadership model is presented in Figure 3.

The standardised coefficient estimates across the nine observed variables on the latent factor Resources varied from 0.61 to 0.77 . The findings suggest that most observed variables have an approximately similar influence in explaining the shared variance in Resources. The standardised coefficient estimates across the nine observed variables on the latent factor Leadership vision varied moderately from 0.61 to 0.82 . The findings suggest that most observed variables have a

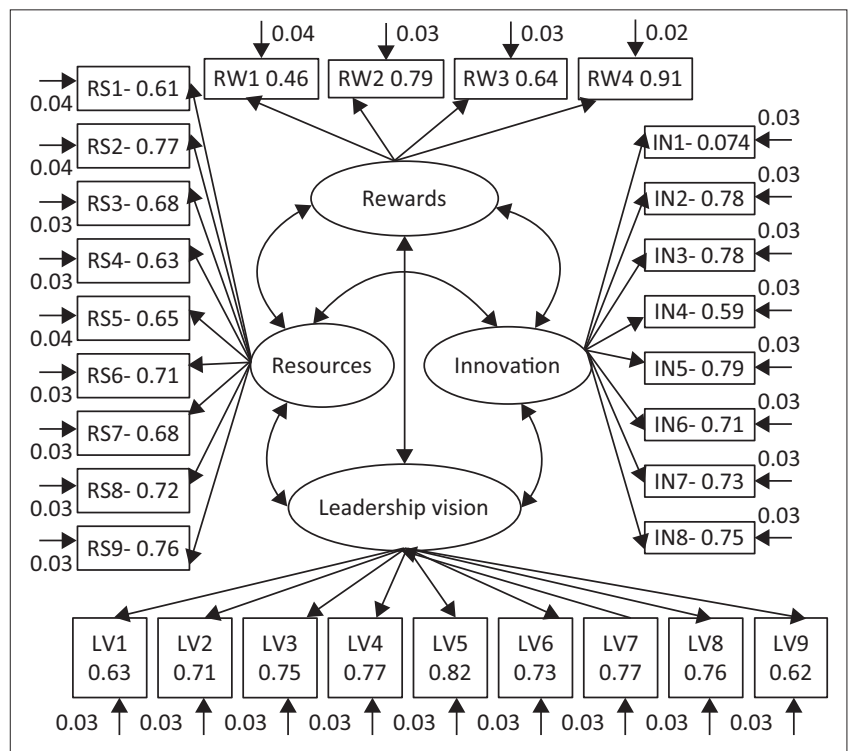

FIGURE 3: Confirmatory factor analysis leadership measurement model results. 
comparable influence in explaining the shared variance in Leadership vision. The standardised coefficient estimate across the eight observed variables of Innovation ranged from 0.58 to 0.78 . The findings indicate that most observed variables $(>0.70)$ had an approximately similar influence in explaining the shared variance in Innovation. All four latent variables had a low root mean square error of approximation (RMSEA) score below the upper limit of 0.6 , which supports a good model fit and is indicative of a significant fit of their observed variables. The researchers could therefore proceed with SEM to test $\mathrm{H} 1, \mathrm{H} 2, \mathrm{H} 3$ and $\mathrm{H} 4$.

\section{Structural equation modelling results}

Confirmatory factor analysis was initially used to provide a confirmatory test of the measurement theory, as depicted in Figure 2, before attempting to further analyse the structural model. The measurement theory, as confirmed by CFA, was then combined with structural theory to fully specify the SEM model. The principal aim is to determine the degree to which the sample data adequately reflect the hypothesised theoretical model.

The structural model, in comparison to the measurement model, allows for regression amongst the latent variables. It identifies relations amongst the unobserved latent variables and indicates how these directly or indirectly influence other latent variables within the model (Byrne, 2012). The results of the SEM are illustrated in Figure 4.

Figure 4 shows how well the hypothesised four factors (latent variables) fit their observed variables. The interrelations between the observed variables loading on rewards ranged from (standardised beta) $\beta=0.64$ to $\beta=0.79$; on resources, from $\beta=0.60$ to $\beta=0.79$; on leadership vision, from $\beta=0.61$ to $\beta=0.80$; and on Innovation, from $\beta=0.59$ to $\beta=0.79$.

The correlation between the latent variables rewards and resources was $r=0.90$; between rewards and leadership vision,

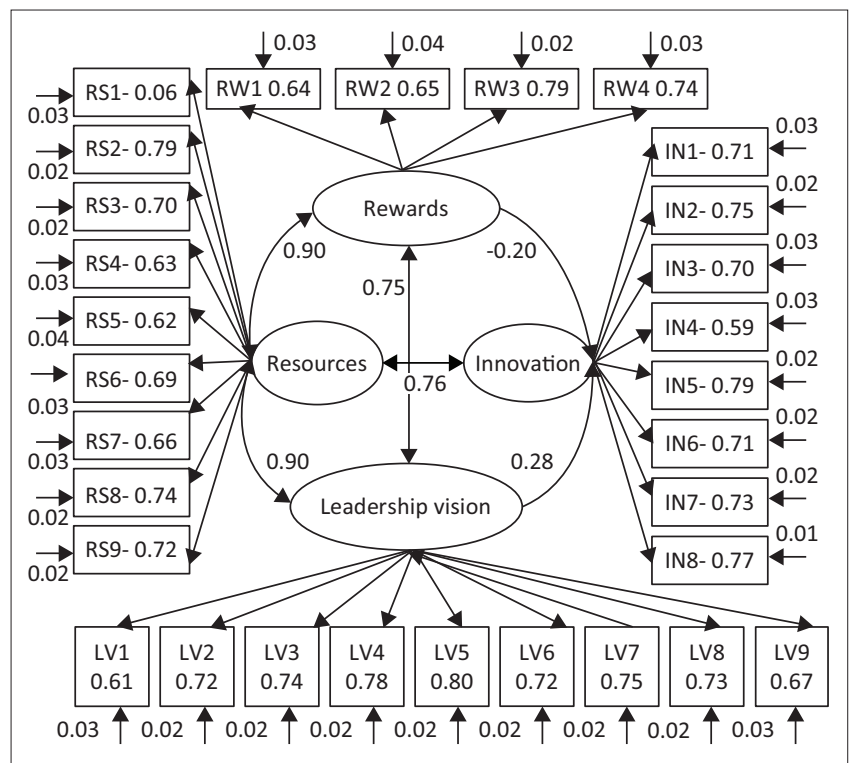

FIGURE 4: The structural equation model. it was $r=0.75$; and between resources and leadership vision, it was $r=0.90$. The factor loading of the exogenous factor rewards on the endogenous factor innovation displayed a negative relationship $(r=-0.02)$. The factor loading of the exogenous factor resources on the endogenous factor Innovation displayed the strongest relationship $(r=0.75)$. The factor loading of the final exogenous factor Leadership vision displayed a reasonably positive relationship $(r=0.28)$ with the endogenous factor Innovation.

\section{Assessing the structural model validity}

The overall fit and the criteria for construct validity were examined by reviewing the key fit statistic and the parameter estimates illustrated in Table 1.

The information in Table 1 indicates the overall fit statistics from testing the leadership model. The chi-square test of model fit $\left(\chi^{2}\right)$ was 994.62 with 399 degrees of freedom $(p<0.00)$. The model (comparative fit index $[\mathrm{CFI}]=0.91)$ was normed to range between 0.00 and 1.00 , with values in close proximity to 1.00 indicative of a good model fit. The RMSEA value (0.051) with a confidence interval of 0.04 to 0.05 is an incremental fit index that relies only on how well the hypothesised model fits the sample data and therefore decreases as goodness-of-fit improves (Byrne, 2012). Given that the RMSEA value was well below that of 0.6 , as recommended by $\mathrm{Hu}$ and Bentler (1999), it can be concluded that the hypothesised theoretical model fits the data sufficiently. The interpretation of the confidence interval revealed that there was $90 \%$ confidence that the RMSEA value of the population will lie between the limits of 0.04 to 0.05 . All of the above measures were within a range associated with good model fit. H4 can therefore be accepted, as there was a significant fit of the latent variables resources, rewards and leadership vision with innovation. The latent variable rewards did not load significantly on the model.

\section{Discussion and interpretation}

The framework of De Jong and Den Hartog (2007) is a nonvalidated conceptual leadership framework. Exploratory research to validate a section of this conceptual framework was embarked on by the present researchers. The limited current literature was complemented by the use of a quantitative method to partially validate the framework, and it is hoped that the results will stimulate future research by other scholars.

TABLE 1: Goodness-of-fit summary model

\begin{tabular}{lc}
\hline Goodness-of-fit statistic & Model \\
\hline Chi-square value & $994.62 *$ \\
Degrees of freedom & 399 \\
$p$-value & 0.00 \\
Scaling correction factor for MLR & 1.60 \\
RMSEA & 0.051 \\
$90 \%$ confidence interval & $0.04-0.05$ \\
CFI & 0.91 \\
\hline CFI, comparative fit index; RMSEA, root mean square error of approximation; MLR, maximum \\
likelihood robust.
\end{tabular}




\section{Impact of rewards on innovation}

The provision of rewards is associated with incentivising employees for specific outcomes. Research on the impact of workplace stimulation and incentivising in organisations has found that enthusiasm and motivation will not materialise without organisations supporting and maintaining employees' interest and encouragement (Cave, 2002). Researchers Deci et al. (1999) established that rewards that satisfy the desire for self-fulfilment have a significant influence on individuals' behavioural patterns, which, in turn, influence their direction and commitment to specific activities. Hence, rewarding a particular behaviour will serve as a motivator for that behaviour. Earlier literature on behavioural theory holds that human behaviour is changeable through the provision of rewards. Behavioural theory suggests that humans will be stimulated and self-motivated if they are rewarded for carrying out certain behaviours and activities (Zhou et al., 1998). The provision of rewards has been related to the inherent motivation of subordinates as a stimulus for innovative outcomes. Kuratko (2009) proposed rewards as one of the five measures that leadership can employ in organisational policies and practices for improving innovative outcomes. Similarly, studies have found that the allocation of rewards in the form of share options, profit-sharing and team incentives enhances employee innovativeness (Antikainen \& Väätäjä, 2010; Mudhi \& Boutellier, 2011). Incentives inspire innovative activities, as subordinates are aware that they are appreciated and recognised for their innovative efforts. This ultimately manifests in an innovative attitude and continuous innovative outcomes throughout the organisation (Walton, 2003).

This study, however, found that rewards was not statistically related to innovation. In fact, the results of the structural model revealed a negative factor loading of $r=-0.02$ of rewards on innovation. This suggested that an increase in the rewards score is related to a slight decrease in the innovation score, which is contradictory to the theoretical postulation. The observed variable loadings on rewards ranged from 0.64 to 0.79 and were within the boundaries of 0.59 and 0.79 for innovation. This suggests that the measured items adequately loaded onto their respective latent factors.

The dissimilar correlation found in the study by De Jong and Den Hartog (2007) could have been the result of the difference between the industries studied, as well as the geographical locations of the respective studies. Whereas rewards may be deemed important for stimulating innovation in a knowledgeintensive industry, the results of this study suggest that this may not be the case in the financial services industry. The difference in geographical locations, that is, Europe versus Africa, may also have contributed to the conflicting findings. Based on the above, with regard to Hypothesis 1, there exists a negative relationship between the provision of rewards and innovation.

\section{Impact of resources on innovation}

The availability of resources revealed a significant positive correlation with innovation, an association that is supported by previous literature (Conroy, 1987; Jang \& Chang, 2008; Weiss et al., 2011; Yuan \& Woodman, 2010), which postulates that if leadership vision includes providing resources (time and money) for innovation, it will serve as a motivator, as it will reflect the organisation's intent to drive and encourage creativity and innovation.

The result was statistically significant, evident from the structural model (Figure 4), where the factor loading of resources on innovation was considerable at $r=0.75$. This represented the strongest relationship of the three exogenous variables on the endogenous variable (innovation) in the model. The observed variable loadings on resources were acceptable, ranging from 0.64 to 0.79 .

The results support the view of previous researchers that innovative efforts are generally demanding activities that require time and adequate resources (Collins, 2012; Mathisen, 2011; Tierney \& Farmer, 2004). Given the many challenges facing organisational innovation, it is crucial that leaders are supportive of the innovative process and make available resources such as money, time and autonomy to ensure that employees remain stimulated and optimistic in continuous innovative practices (Mathisen, 2011).

The results of this study show that the more resources an organisation makes available for innovation, the more prevalent innovative activities and outcomes will become. Employees with access to resources tend to be stimulated by the availability of these resources and will carry out innovative practices. They will be more encouraged to take on new and innovative activities, knowing that they have the necessary organisational support to follow through with their ideas and that their creativity and efforts will not be wasted, as there is appropriate support to undertake the different phases of the innovation process, that is, research, implementation and testing. Based on the above, with regard to Hypothesis 2, providing resources has a significant positive correlation with innovation.

\section{Impact of leadership vision on innovation}

Leadership vision entails providing a statement of objectives that employees can honourably pursue to reach the organisation's future goals (James \& Lahti, 2011). It represents the direction or approach of an organisation and presents the future strategy that the company needs to follow (Revilla \& Rodriguez, 2011; Schwarz \& Nandhakumar, 2002). A strategic vision encompasses the organisation's future goals and aspirations, which portray the orientation the company will pursue within its competitive realm (Camelo-Ordaz et al., 2008; Raynor, 1998). Having a clear vision therefore positions subordinates to practise specific outcomes aligned with the organisation's strategy and direction. 
Leadership vision showed a weak positive, yet significant, relationship with innovation $(r=0.28)$ in the structural model, compared to the more significant latent factor resources $(r=$ 0.75). Nevertheless, providing leadership vision in terms of strategy and direction did demonstrate a reasonably positive correlation with innovation. This is supported by research by O'Conell et al. (2011) and by Slack et al. (2010), for instance, who view vision as having a significant relationship with individual employee creativity and stimulation, as well as with team innovation. Similarly, Chandi and Tellis (1998) utilised an extensive sample of over 300 companies in a study that revealed that leadership's vision has a strong impact on innovation.

Hülsheger et al. (2009) established a positive correlation $(r=0.41)$ between vision and team innovation, with vision signifying a motivating force towards innovative practices. Supplementary to the above, Slettan and Mehmetoglo (2011) investigated the relationship between the two variables in the hospitality industry and found a favourable interrelation between the two constructs $\left(r^{2}=18.8 \%\right)$, suggesting that a company's vision has an influence on employees' thoughts and actions. Therefore, high scores relating to the leadership vision items are indicative that employees are more likely to pursue their innovative efforts in line with the direction of the organisation's intent. Conversely, subordinates scoring lower on this dimension may not pay attention to the organisation's long-term vision and strategy, and may be focused more on the short term. While innovation is valuable, it needs to be aligned with the roadmap of where the organisation is going in terms of future vision and direction in order for the outcome to be beneficial to the organisation. With regard to Hypothesis 3, it was determined that providing vision has a significant positive relationship with innovation.

Based on the theoretical findings, the three latent leadership variables, rewards, resources and leadership vision, were found to be positively related to innovation. However, the results of the SEM revealed that only leadership vision and resources were found to be statistically significant; rewards showed a negative relationship $(r=-0.02)$ with innovation. Resources made the greater contribution $(r=0.75)$ to innovation, compared to leadership vision $(r=0.28)$.

In conclusion, the results of the study empirically validate and support the assertion of De Jong and Den Hartog (2007) that the latent variables resources and leadership vision positively correlate with innovation in the context of the financial services industry.

\section{Limitations of the study}

This study centred around theory underpinning leadership's need to drive innovation in the 21st century, highlighting dimensions on which leadership can focus to stimulate innovative practices within the workplace. The literature survey could have incorporated more recent articles; however, the researchers focused on articles covering the available latent variables. Generalising of the results to other organisations or geographical locations should be done with caution, but is encouraged. As secondary raw data from only one organisation and sector were used, data from other organisations or locations may yield dissimilar results. Moreover, the study was limited to a selection of four dimensions (latent variables) gleaned from the framework of De Jong and Den Hartog (2007), thereby offering a partial validation of their leadership model.

\section{Suggestions for future study}

This study had some restrictions that present opportunities for further research. As this study was limited to the financial services industry, suggestions for future research include analysis of leaders in other sectors, to determine applicability of the variables in relation to innovation across different environments. As only four latent variables were evaluated during this study, there is scope for further analysis of the other variables in the framework of De Jong and Den Hartog (2007) that postulated to have an influence in stimulating innovation. In addition, as both this study and that of De Jong and Den Hartog (2007) were confined to the analysis of leaders, further investigation could evaluate subordinates' perspectives, to gain a broader viewpoint of stimuli for innovation.

\section{Acknowledgements}

This article was extracted from S. Naidoo's minor dissertation under the supervision of Prof. L.M.M. Hewitt. It is expected that the similarity index will be high between the articles and minor dissertation. However, extensive literature was added by Prof. Hewitt and Prof. M. Bussin. The statistical outcomes will of course be the same.

\section{Competing interests}

The authors declare that they have no financial or personal relationships that may have inappropriately influenced them in writing this article.

\section{Authors' contribution}

S.N. is the principal researcher and prepared the first draft of the article based on his minor dissertation. L.M.M. is the supervisor of the study and refined the draft to a publishable article. M.B. added value and theoretical depth based on his knowledge and expertise on the topic of rewards, as well as driving the publication of this article.

\section{References}

Afuah, A. (1998). Innovation management: Strategies, implementation, and profits. New York: Oxford University Press.

Akhtar, S. (2010). Effects of knowledge and leadership. World Applied Science Journal, 10(2), 173-178.

Allcorn, S. (2012). Ending the clash between management's desire for control and innovation. MWorld, 11(1), np.

Amabile, T. M., Conti, R., Coon, H., Lazenby, J., \& Herron, M. (1996). Assessing the work environment for creativity. Academy of Management Journal, 39(5), 1154-1184. 
Amar, A. D., Hentrich, C., \& Hlupic, V. (2009). To be a better leader, give up authority. Harvard Business Review, 87(12), 22-25.

Antikainen, M., Makipaa, M., \& Ahohen, M. (2010). Motivating and supporting collaboration in open innovation. European Journal of Innovation Management, 13(1), 100-119. https://doi.org/10.1108/14601061011013258

Antikainen, M., \& Väätäjä, H. (2010). Rewarding in open innovation communities How to motivate members? International Journal of Entrepreneurship and Innovation Management, 11, 440-456. https://doi.org/10.1504/IJEIM.2010. 032267

Aryee, S., Walumbwa, F. O., Zhou, Q., \& Hartnell, C. A. (2012). Transformational leadership, innovative behavior, and task performance: Test of mediation and moderation processes. Human Performance, 25(1), 1-25. https://doi.org/10.1080 /08959285.2011.631648

Axtell, C. M., Holman, D. J., Unsworth, K. L., Wall, T. D., Waterson, P. E., \& Harrington E. (2000). Shop floor innovation: Facilitating the suggestion and implementation of ideas. Journal of Occupational \& Organizational Psychology, 73, 265-285. https://doi.org/10.1348/096317900167029

Balkin, D. B., \& Gomez-Mejia, L. R. (1990). Matching compensation and organizationa strategies. Strategic Management Journal, 11(2), 153-169. https://doi.org/ $10.1002 /$ smj.4250110207

Bragg, T. (2000). How to effectively reward and inspire your team. Occupational Hazards, 69(10), 131

Byrne, B. M. (2012). Structural equation modelling with Mplus, basic concepts, applications and programming. New York: Routledge.

Calcantone, R. J., Cavusgil, S. T., \& Zhao, Y. (2002). Learning orientation, firm innovation capability, and firm performance. Industrial Marketing Management, 31 515-524. https://doi.org/10.1016/S0019-8501(01)00203-6

Campbell, N., \& Collins, A. (2001). In search of innovation. CPA Journal, 71(4), 26-35.

Campbell-Allen, N., Houston, D., \& Mann, R. (2008). Best practices in New Zealand organizations for rewarding and recognizing employee innovations and achievements. Total Quality Management, 19(2), 125-139. https://doi.org/ 10.1080/14783360701602031

Camelo-Ordaz, C., Fernandez-Alles, M., \& Valle-Cabrera, R. (2008). Top Management team's vision and human resources management practices in innovative Spanish companies. The International Journal of Human Resource Management, 19(4), 620-638. https://doi.org/10.1080/09585190801953665

Cavagnoli, D. (2011). A conceptual framework for innovation: An application to human resource management policies in Australia. Innovation: Management, Policy \& Practice, 13. Melbourne, VIC: University of Melbourne.

Chandi, R. K., \& Tellis, G. J. (1998). Organizing for radical product innovation: The overlooked role in willingness to cannibalise. Journal of Marketing Research, 35(4), 474-487. https://doi.org/10.1177/002224379803500406

Collins, D. (2012). Applying collaborative innovation to design thinking. Retrieved from http://www.innovationmanagement.se/2012/01/24/applying-collaborativeinnovation-to-design-thinking/

Cook, P. (1998). The creativity advantage - Is your organization the leader of the pack? Industrial and Commercial Training, 30(5), 179-184. https://doi.org/10.1108/ 00197859810225652

Cooper, R. J. (1998). A multidimensional approach to the adoption of innovation. Management Decision, 36(8), 493-502. https://doi.org/10.1108/00251749810 232565

Conroy, C. (1987) cited in: The cutting edge. Non Profit World, 5(5). Creativity Research Unit Technical Report (2008). Leadership for Innovation: A Global Climate Survey-A
CRU Technical Report, Creativity Research Unit, The Creative Problem Solving Group, Inc., Buffalo, NY

Damanpour, F. (1991). Organizational innovation: A meta-analysis of effects of determinants and moderators. Academy of Management Journal, 34(3), 555-590.

Deci, E., Koestner, R., \& Ryan, R. (1999). A meta-analytic review of experiments examining the effects of extrinsic rewards on intrinsic motivation. Psychological Bulletin, 125, 627-668. https://doi.org/10.1037/0033-2909.125.6.627

Deci, E. L., \& Ryan, R. M. (1987). The support of autonomy and the control of behavior Journal of Personality and Social Psychology, 53, 1024-1037. https://doi.org/ 10.1037/0022-3514.53.6.1024

De Jong, J. P. J., \& Den Hartog, D. N. (2007). How leaders influence employees' innovative behaviour. European Journal of Innovation Management, 10(1), 41-64. https://doi.org/10.1108/14601060710720546

Elenkov, D. S., \& Manev, I. M. (2005). Top management leadership and influence on innovation: The role of socio cultural context. Journal of Management, 31(3), 381-402. https://doi.org/10.1177/0149206304272151

Finkelstein, S., \& Hambrick, D. C. (1990). Top management team tenure and organisational outcomes: The moderating role of managerial discretion. Administrative Science Quarterly, 35, 484-494. https://doi.org/10.2307/2393314

George, J. M., \& Jones, G. R. (2008). Understanding and managing organisational behavior. New Jersey: Pearson Education, Inc.

George, J. M., \& Zhou, J. (2001a). When openness to experience and conscientiousness are related to creative behaviour: An interactional approach. Journal of Applied Psychology, 86, 513-524. https://doi.org/10.1037/0021-9010.86.3.513

George, J. M., \& Zhou, J. (2001b). When job dissatisfaction leads to creativity: Encouraging the expression of voice. Academy of Management Journal, 44(4), 682-696.

Glynn, M. A. (1996). Innovative genius: A framework for relating individual and organizational intelligences to innovation. Academy of Management Review, 21(4), 461-473. https://doi.org/10.5465/amr.1996.9704071864
Gumusluoğlu, L., \& Ilsev, A. (2009). Transformational leadership and organizational innovation: The roles of internal and external support for innovation. Journal of Product Innovation Management, 26, 264-277. https://doi.org/10.1111/j.1540Product Innovation

Gupta, A. K., \& Singhal, A. (1993). Managing human resources for innovation and creativity. Research Technology Management, 36(3), 41-48. https://doi.org/ 10.1080/08956308.1993.11670902

Hair, J. F., Anderson, R. E., Tatham, R. I., \& Black, W. C. (1995). Multivariate data analysis (3rd edn.). Englewood Cliffs, NJ: Prentice Hall.

Hennessey, B. A., \& Amabile, T. M. (1998). Reality, intrinsic motivation, and creativity. American Psychologist, 53(6), 674-675. https://doi.org/10.1037/0003-066X. 53.6.674

$\mathrm{Hu}$, L., \& Bentler, P. M. (1999). Cut-off criteria for fit indexes in covariance structure analysis: Conventional criteria versus new alternatives. Structural Equation Modelling, 6(1), 1-55.

Hülsheger, U. R., Anderson, N., \& Salgado, J. F. (2009). Team-level predictors of innovation at work: A comprehensive meta-analysis spanning three decades of research. Journal of Applied Psychology, 94(1), 1128-1145. https://doi.org/ 10.1037/a0015978

Itami, H., \& Numagami, T. (1992). Dynamic interaction between strategy and technology. Strategic Management Journal, 13, 119-135. https://doi.org/ technology. Strategic $N$
$10.1002 /$ smj.4250130909

Jafri, M. H., \& Bhutan, G. (2010). Organizational commitment and employees' innovative behavior: A study in retail sector. Journal of Management Research, 10(1), 62-68.

James, K., \& Lahti, K. (2011). Organizational vision and system influences on employee inspiration and organizational performance. Journal of Creativity and Innovation Management,20(2),108-120. https://doi.org/10.1111/j.1467-8691.2011.00595.x

Jang, W. S., \& Chang, W. (2008). The impact of financial support system on technology innovation: A case of technology guarantee system in Korea. Journal of Technology, Management and Innovation, 3(1), 10-16.

Jarousse, L. A. (2012). Making innovation a core competency. Trustee, 65(5), 26-27.

Ju, B. (2012). An evaluation of critical factors influencing product innovation in the food industry - A case study of China Mengniu Dairy Company. Journal of Business and Management, 7(3), 1833-8119.

Kline, R. B. (2011). Principles and practices of structural equation modeling (3rd edn.). New York: The Guilford Press.

Kim, D., \& Kogut, B. (1996). Technological platforms and diversification. Organization Science, 7(3), 283-301. https://doi.org/10.1287/orsc.7.3.283

Kuratko, D. F. (2009). Introduction to entrepreneurship (8th edn.). Mason, OH: SouthWestern Cengage Learning.

Leiva, I. P., Culbertson, S. S., \& Pritchard, R. D. (2011). An empirical test of an innovation implementation model. The Psychologist-Manager Journal, 14, 265-281. https:// doi.org/10.1080/10887156.2011.621780

Liao, L. F. (2006). A learning organisation perspective on knowledge-sharing behaviour and firm innovation. Human Systems Management, 25, 227-236.

Lin, C. Y., \& Chang Jung, C. (2006). Influencing factors on the innovation in logistics technologies for logistics service providers in Taiwan. The Journal of American Academy of Business, 9(2), 613-631.

Mathisen, G. E. (2011). Organizational antecedents of creative self-efficacy. Creativity and Innovation Management, 20(3), 185-195. https://doi.org/10.1111/j.14678691.2011.00606.x

Morton, N. (2011). Validation of a preliminary soft-heartedness scale within the South African Personality Inventory. Minor dissertation, University Of Johannesburg, South Africa. Retrieved from https://ujcontent.uj.ac.za/vital/access/manager/ Repository?query=Validation+of+a+preliminary+soft-heartedness+scale+within+ Repository?query=Validation+of+a+preliminary+soft-heartedness
the+South+African+Personality+Inventory\&queryType=vitalDismax

Mukundan, G. (2006). Innovation for competitive advantage. Journal of Advanced Manufacturing Systems, 5(1), 1-2. https://doi.org/10.1142/S0219686706000753

Mudhi, L., \& Boutellier, R. (2011). Motivational factors affecting participation and contribution of members in two different Swiss innovation communities. International Journal of Innovation Management, 15(3), 543-562. https://doi. org/10.1142/S1363919611003477

Nanus, B. (1996). Leading the vision team. The futurist. The Journal of Management Development. 30, 20-23.

Negrusa, A. L., Gica, O. A., \& Cosma, S. A. (2008). SMEs' innovation activity: Case of Transylvania Region, Romania. Journal of International Business and Economics, $8(2), 79-85$

Nobeoka, K., \& Cusumano, M. (1997). Multiproject strategy and sales growth: The benefits of rapid design transfer in new product development. Strategic Management Journal, 18(3), 169-186. https://doi.org/10.1002/(SICI)10970266(199703)18:3<169::AID-SMJ863>3.0.CO;2-K

O'Conell, D., Hickerson, K., \& Pillutla, A. (2011). Organizational visioning: An integrative review. Group \& Organization Management, 36(1), 103-125. https://doi.org/ $10.1177 / 1059601110390999$

Oldham, G. R., \& Cummings, A. (1996). Employee creativity: Personal and contextual factors at work. Academy of Management Journal, 39(3), 607-634.

Parker, A. J. (2007). The validity of world class business criteria across developed and developing countries. Doctoral dissertation, University of Johannesburg, South Africa.

Poster, C. Z., \& Scannella, J. (2001). Total rewards in an ideal world. Benefits Quarterly, $17(3), 23-28$. 
Raynor, M. E. (1998). That vision thing: Do we need it? Long Range Planning, 31(3), 368-376. https://doi.org/10.1016/S0024-6301(98)80004-6

Revilla, E., \& Rodríguez, B. (2011). Team vision in product development: How knowledge strategy matters. Technovation, 3(1), 118-127. https://doi.org/10. 1016/j.technovation.2010.10.007

Roy, S., Sivakumar, K., \& Wilkinson, F. I. (2004). Innovation generation in supply chain relationships: A conceptual model and research propositions. Journal of the Academy of Marketing Science, 32(1), 61-69. https://doi.org/10.1177/00920 70303255470

Ruppel, C. P., \& Harrington, S. J. (2000). The relationship of communication, ethical work climate, and trust to commitment and innovation. Journal of Business Ethics, 25(4), 313-328. https://doi.org/10.1023/A:1006290432594

Schermerhorn, J. R. (2005). Management. Bristol, UK, John Wiley \& Sons.

Schwarz, M., \& Nandhakumar, J. (2002). Conceptualizing the development of strategic ideas: A grounded theory analysis. British Journal of Management, 13(1), 67-83. https://doi.org/10.1111/1467-8551.00223

Scott, S. G., \& Bruce, R. A. (1994). Determinants of innovative behavior: A path model of individual innovation in the workplace. Academy of Management Journal, 37(3), 580-607.

Senge, P. M. (1990). The leader's new work: Building learning organizations. Sloan Management Review. 32(1), 7-23.

Shin, S. J., \& Zhou, J. (2003). Transformational leadership, conservation and creativity Evidence from Korea. Academy of Management Journal, 46(6), 703-714. https:// doi.org/10.5465/30040662

Slack, F. J., Orife, J. N., \& Anderson, F. P. (2010). Effects of commitment to corporate vision on employee satisfaction with their organization: An empirical study in the United States. International Journal of Management, 27, 421-436.

Slettan, T., \& Mehmetoglu, M. (2011). What are the drivers for innovative behaviour in frontline jobs? A study of the hospitality industry in Norway Department of Tourism. Journal of Human Resources in Hospitality \& Tourism, 10, 254-272. https://doi.org/10.1080/15332845.2011.555732

Smith, G. P. (2002). The new leader: Bringing creativity and innovation to the workplace, chart your course. Conyers, GA: Emerald Group Publishing Limited.

Song, M., \& Noh, J. (2006). Best new product development and management practices in the Korean high-tech industry. Industrial Marketing Management, 35(3), 262-278. https://doi.org/10.1016/j.indmarman.2005.04.007

Starratt, R. (1995). Leaders with vision: The quest for school renewal. Thousand Oaks, CA: Corwin Press.
Subramaniam, I. D., \& Moslehi, M. M. (2013). Does workforce innovation mediate the relationship between internal factors and performance in Malaysian entrepreneurial SMEs? Asian Social Science, 9(9), 1911-2017. https://doi.org/ entrepreneurial SMEs?

Tierney, P., \& Farmer, S. M. (2004). The Pygmalion Process and Employee Creativity. Journal of Management, 30, 413-432. https://doi.org/10.1016/j.jm.2002.12.001

Unsworth, K. L., \& Parker, S. K. (2003). Promoting a proactive and innovative workforce for the new workplace. Chichester: John Wiley \& Sons.

Vroom, V. H., \& Jago, A. G. (2007). The role of the situation in leadership. American Psychologist, 62(1), 17-24. https://doi.org/10.1037/0003-066X.62.1.17

Walton, A. P. (2003). The impact of interpersonal factors on creativity. International Journal of Entrepreneurial Behaviour \& Research, 9(4), 146-162. https://doi. org/10.1108/13552550310485120

Ward, T. B. (1994). Structured imagination: The role of category structure in exemplar generation. Cognitive Psychology, 27(1), 1-40. https://doi.org/10.1006/cogp. 1994.1010

Weiss, M., Hoegl, M., \& Gibbert, M. J. (2011). Making virtue of necessity: The role of team climate for innovation in resource-constrained innovation projects. Product Development \& Management Association, 28(1), 196-207. https://doi.org/ 10.1111/j.1540-5885.2011.00870.x

Wiklund, J., Patzelt, H., \& Shepherd, D. (2009). Building an integrative model of small business growth. Small Business Economics, 32(4), 351-374. https://doi.org/ 10.1007/s11187-007-9084-8

Yuan, F., \& Woodman, R. W. (2010). Innovative behavior in the workplace: The role of performance and image outcome expectations. Academy of Management Journal, 53(2), 323-342. https://doi.org/10.5465/amj.2010.49388995

Yukl, G. (2002). Leadership in organizations (5th edn.). Englewood Cliffs, NJ: Prentice-Hall.

Zauškováa, A., Bobovnickýa, A., \& Madleňáka, A. (2013). How can the state support innovations to build a sustainable competitive advantage of the country? Serbian Journal of Management, 8(2), 255-267. https://doi.org/10.5937/sjm8-4430

Zhao, F. (2005). Exploring the synergy between entrepreneurship and innovation International Journal of Entrepreneurial Behaviour \& Research in Organizational Behaviour, 11(1), 25-41. https://doi.org/10.1108/13552550510580825

Zhou, Y., Zhang, Y., \& Montoro-Sanchez, A. (1998). How do reward approaches affect employees' innovative behaviours? - An empirical study in Chinese enterprises. Beijing: University of China, School of Business.

Zikmund, W. G., Babib, J. B., Carr, C. J., \& Griffen, M. (2011). Business research methods (9th edn.). Mason, OH: South-Western. 